\title{
Bridge the Gaps-An Allied Naval Approach for Northern Europe
}

Julian Pawlak ${ }^{1}$

\section{Introduction}

Following 1990, Northern European waters appeared to be a neglected part of allied maritime strategic thought until NATO's recent paradigm change. ${ }^{2}$ Despite security concerns from some of its littoral states which never fully vanished, the maritime operational areas, more precisely the Baltic, the Norwegian and North Seas, as well as their linkage to the North Atlantic, did not receive the strategic attention they deserved. ${ }^{3}$ They continued to oscillate between "Bastion, Backwater or Battlefront". ${ }^{4}$ As the Western alliance finally acknowledged the renewed strategic rivalry it has to face today, it initiated a fundamental turning point. Repercussions, such as increased military and subversive activities, are apparent and pronounced most in the region this chapter deals with, impacted by the backdrop of renewed competition between the great powers. ${ }^{5}$ The setback to-

1 The author wants to thank Sebastian Bruns for his inspirational remarks on this chapter.

2 Rainer Meyer zum Felde, "Abschreckung und Dialogbereitschaft - der Paradigmenwechsel der NATO seit 2014“, SIRIUS - Zeitschrift für Strategische Analysen, vol. 2 (2), 2018, 101-117.

3 Rebecca Pincus, "Towards a New Arctic. Changing Strategic Geography in the GIUK Gap”, the RUSI Journal, vol. 165 (2020), Issue 3, 53-54.

4 Jeremy Stöhs, "Bastion, Backwater, or Battlefront? Changing Strategic Views Along Europe's Northern Shores", in Conceptualizing Maritime \& Naval Strategy. Festschrift for Captain Peter M. Swartz, United States Navy (ret.), eds. Sebastian Bruns and Randy Papadopoulos (Baden-Baden: Nomos, 2020), 321-344.

5 The present great power competition was acknowledged largely following its mentioning in the 2015 National Military Strategy and the 2017 National Security Strategy of the United States, where it was described as the global competition between the US, Russia and China. Whilst this chapter deals predominantly with Russia as NATO's main competitor in the particular region, China and the CCP's global intentions play an ever-growing role there as well. The PLAN's first visits to the Nordic-Baltic region, Chinese claims in the Arctic, and its naval build-up indicate its activities will increase in those theatres too. Hence, allies will need to prepare to deal with the naval activities of more than one contender. 
wards this antagonism and the ultimate fear of an escalating military conflict in the region brought the respective theatres back onto the security policy agenda of European and NATO capitals.

This chapter features the theatres illustrated in an allied (here: NATO) context. These areas figure as components of a combined strategic realm, the so-called Northern Flank. ${ }^{6}$ Such a depiction promotes the aim of this article, that is, to make the case for a combined strategic approach in Northern Europe. ${ }^{7}$ To wit, it does not intend to lessen regionalisation efforts, but to highlight the extensive strategic outline. The beginning refers to the strategic fundamentals: it defines the Northern Flank, clarifies its relevance as a whole, and stresses a strategic Euro-Atlantic approach. The article provides an overview of the setting and briefly accentuates allied initiatives and cross-theatre challenges. ${ }^{8}$ It concentrates on the high end of naval challenges, links the operational areas in the region and finally provides recommendations to bridge the gaps for an allied naval approach.

\section{Definition and setting}

The region of interest encompasses various maritime areas of operation. On the one hand, it includes the North Sea and the North Atlantic. On the other, it encircles the shallow and confined Baltic Sea region, as well as the abyssal Norwegian Sea up to the High North. Each theatre provides the

6 During the Cold War, the term "flank" served originally as the region's ascription to its role as a tactical northern flank "subordinate to and part of the more central [European] battlefront". Gjert Lage Dyndal, "The Northern Flank and the High North Scenarios of the Cold War", Paper held at conference: 'Peripherie oder Kontaktzone? Die NATO-Flanken 1961 bis 2013’, Zentrum für Militärgeschichte und Sozialwissenschaften der Bundeswehr, Potsdam, Germany, 2013, 13. Originally concerning the Baltic Sea and Southern parts of Scandinavia, its focus shifted further north. Eventually, the areas up to the High North served as "peripheral theatres of war". ibid. In this analysis, the strategic Northern Flank helps to sum up the selected areas of operation in Northern Europe for an allied approach.

7 See also Rowan Allport, Fire and Ice - A New Maritime Strategy for NATO's Northern Flank (Human Security Centre 2018).

8 Due to the limited scope this chapter offers, its overview of military challenges and capabilities remains a concise breakdown instead of an intensive tour d'horizon. Whilst its focus continues to be on the high end of military escalation, it does not go deeply into numbers and capacities. Several authors have examined the operational areas illustrated here recently. See Magnus Nordenman (2019) on the North Atlantic or Heinrich Lange et al. (2019) and Martin Murphy et al. (2016) on the Baltic Sea. 
strategic planner with its own prominent gap, supposedly recalled as its own Achilles heel. The GIUK gap, the Bear gap and the Suwałki gap are addressed here. While the latter represents the land connection between Poland and Lithuania, both others are maritime corridors. ${ }^{9}$ In detail, the GIUK gap encompasses the area between Greenland, Iceland and the United Kingdom. ${ }^{10}$ Its reputation still lives off its high profile which originated from the Cold War, ${ }^{11}$ although a similar calculated threat of large-scale penetrations by Russian naval assets seems most unlikely for the time being. ${ }^{12}$ Nevertheless, the gap embodies "a strategic corridor for naval operations between the Arctic and the North Atlantic", ${ }^{13}$ and therefore the geo-

9 Whether the three cases mentioned in fact represent gaps or should be labelled as operational corridors for passage and/or wider strategic chokepoints may be debatable and varies in the research literature. As the following shows, their strategic significance surpasses a limitation on their operational theatres in any case.

10 Including Norway, it is the designated GIUK-N gap.

11 The Gap's legacy relates primarily to its role as a gateway for the alleged Soviet intention to fight a "Battle for the Atlantic III" by challenging NATO SLOCs, although its relevance has been pointed out beforehand, including the vital role of the United States' outposts on Iceland or Greenland. See Pincus, "A New Arctic", $50 \mathrm{ff}$. The former still remains a key reference, even though such assumptions proved wrong. See Dismukes, Bradford, "The Return of Great-Power Competition-Cold War Lessons about Strategic Antisubmarine Warfare and Defense of Sea Lines of Communication", Naval War College Review, vol. 73 (2020) No. 3, art. 6, 3-6.

12 Yet, North American reinforcements via the North Atlantic would allowedly alter the vast ocean into a target-rich environment. Given the case of an article five conflict in Europe, decreasing such reinforcements would be in Russia's interest to avoid the alliance's full military potential on the continent-if it were not for the current lack of capacities to do so in an ample way. Certainly, one can expect individual Russian submarines like the Yasen-class to be diving in the depths of the Atlantic by now. However, in consideration of the Russian Navy's (particularly the Northern Fleet's) main tasks, the fleet would be presumably working at full capacity by that already. The major one, the Bastion defence concept, contains the end of sea control in the inner Bastion segment (the Barents Sea and the High North), along with the attempt to deny the Norwegian Sea, the outer bastion, to NATO and allied forces, all with its current numbers and condition. With the emergence of UUVs, USVs and further unmanned systems, the approach might evolve in future. See also: Steve Wills, “These aren't the SLOC's you're looking for': mirror-imaging battles of the Atlantic won't solve current Atlantic security needs", Defense \& Security Analysis, 36,1 (2020), 9-10.

13 United States Department of Defense, "Report to Congress. Department of Defense Arctic Strategy", Office of the Under Secretary of Defense for Policy, June 2019. https://media.defense.gov/2019/Jun/06/2002141657/-1/-1/1/2019-DOD-ARC TIC-STRATEGY.PDF. 
graphically entailed access to NATO's traditional home waters for most of Europe and the Russian West, likewise. ${ }^{14}$ The Suwałki gap, the short land border of the two NATO members, is around $65 \mathrm{~km}$ wide. ${ }^{15}$ Its presence in the allied security policy discourse evolved mainly due to the 2014 war in Ukraine. The Suwałki area remains the only direct land corridor connecting the three Baltic NATO members with Poland and their further allies, and therefore underscores its strategic significance for allied reinforcements. ${ }^{16}$ Cutting it off would risk Baltic integrity. As a third area, the Bear gap represents the maritime region between the Northern Norwegian mainland and the Svalbard archipelago, ${ }^{17}$ including Bear Island midway. It is a landmark for the beginning of the Russian Navy's inner bastion segment. ${ }^{18}$ It symbolises the passage its vessels need to take in heading towards the Norwegian Sea and further South. Additionally, the other way around, it is one of the "entrances" to the Arctic. ${ }^{19}$

14 Benjamin Rhode, "The GIUK gap's strategic significance”, IISS Strategic Comments, vol. 25 comment 29, October 2019.

15 Linear distance. Its name comes after the Polish town Suwałki.

16 Its purpose and the shortcomings regarding the defence of the three Baltic States are revealed most famously by a prevalent RAND study. See David A. Shlapak and Michael Johnson, Reinforcing Deterrence on NATO's Eastern Flank. Wargaming the Defense of the Baltics (Santa Monica, CA: RAND Corporation, 2016). https://w ww.rand.org/pubs/research_reports/RR1253.html.

17 The archipelago was placed under Norwegian sovereignty with the signing of the Spitsbergen Treaty in 1920. Since its entrance into force in 1925, the island group has been under Norwegian administration. While the signatory nations are able to follow economic activities there, the territory itself is demilitarised and does not allow the permanent stationing of military forces.

18 As explained in footnote 11.

19 On Russian military forces and missions in the High North, see Katarzyna Zysk: "Russia's Military Build-Up in the Arctic: to What End?", CNA occasional paper, September 2020. 
Northern Europe with the three gaps and the Russian Bastion segments. ${ }^{20}$

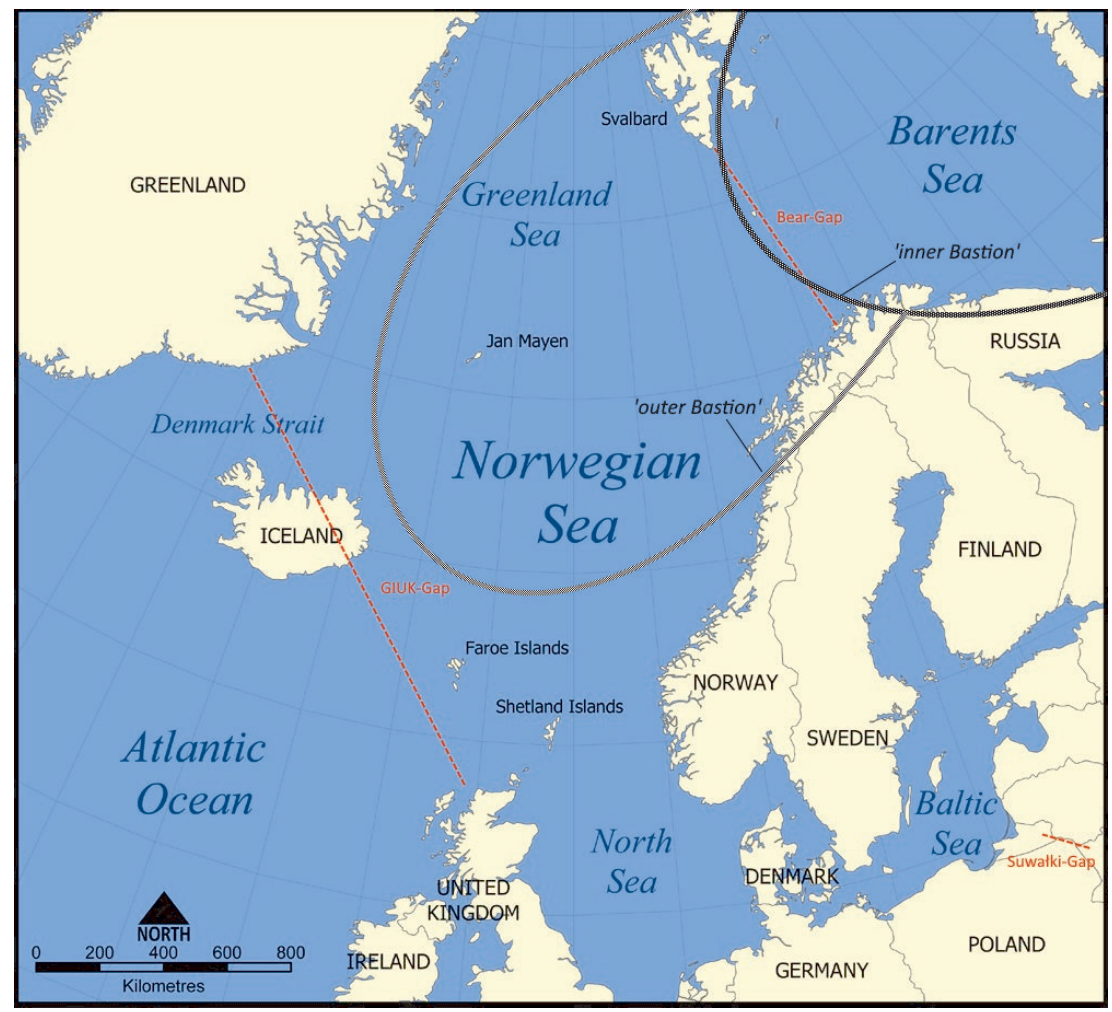

Each section is seen as a linchpin in its respective operational area and accommodates unique characteristics and challenges. Nevertheless, particularly in a high-end conflict scenario, any military escalation would hardly stay limited to a particular area. Quite the contrary, the risk of a broad spread of military operations into the wide range of the defined Northern Flank would be high. ${ }^{21}$ Even if one considers different types of military risks in the region, namely on the high and low levels of armed conflict,

20 Map by Norman Einstein, published under the GNU Free Documentation License (GFDL). Own adjustments included. https://commons.wikimedia.org/wiki/ File:Norwegian_Sea_map.png. Please note that any added mark represents only a broad indication of the strategic objects.

21 Conflict and escalation scenarios vary from deliberate to unintended escalation, like launching a weapon by accident. Of course, incidents might occur simultane- 
the complexity of strategic circumstances may even result in the smallest incidents setting the ball rolling. In other words, even primary limited (non-)military action in or against a NATO member state could cause military support from the whole alliance and even trigger Art. V. ${ }^{22}$ Therefore, while the Baltic Sea region might offer the potential to spark presumably confined conflicts due to low-level incidents and grey-zone challenges, allied representatives identify the Norwegian Sea and High North as an area of impact by horizontal escalation originating in adjacent theatres. ${ }^{23}$ In any case, allied naval forces have to be prepared to collaborate on challenging activities in Northern European waters, while mindful of the risk of spillover effects around the continent. While European military forces in particular might be able to deal with limited single sources of fire, the effort of collective defence is in need of a structured strategic framework. ${ }^{24}$ Thus, going into detail at that point argues reasonably for an allied naval approach for the Northern Flank.

\section{Recent initiatives and cross-theatre challenges}

Current initiatives mark the significance of collective defence in the alliance's current naval posture. They include the (re-) establishment of the

ously in different areas and on different stages. See Ulrich Kühn, Preventing Escalation in the Baltic. A NATO Playbook (Carnegie Endowment for International Peace, 2018). https://carnegieendowment.org/files/Kuhn_Baltics_INT_final_WEB .pdf.

22 Even though this chapter is limited on an approach related to high-intensity conflicts, it is relevant to acknowledge that the casus foederis is not limited to expected Cold War era-like attacks that rely on military means. Since alliances such as NATO "have succeeded in deterring interstate military disputes, adversaries are seeking means of changing the status quo through security incidents short of an armed attack". See Michael M. Bosack, "Ameliorating the Alliance Dilemma in an Age of Grey-Zone Conflict-Lessons Learned from the U.S.-Japan Alliance”, Naval War College Review, vol. 73 (2020), No. 4, art. 5, 2.

23 Covering the Baltic Sea region, the "reversed Las Vegas rule" applies: what happens in the Baltic does not stay in the Baltic. See Julian Pawlak and Sebastian Bruns, "Die Ostsee ist nicht Las Vegas. Das Mare Balticum im sicherheitspolitischen Kontext", Marine Forum 6-2019, 20-35. James Black et al., Enhancing deterrence and defence on NATO's northern flank. Allied perspectives on strategic options for Norway (Santa Monica, CA: RAND Corporation, 2020). https://www.rand.org/pu bs/research_reports/RR4381.html.

24 Svein Elfjestad, "Norway and the North Atlantic: Defence of the Northern Flank", Whitehall Papers, 87, 1 (2017), 62. 
NATO Atlantic Command/Joint Forces Command Norfolk and the US Navy's $2^{\text {nd }}$ Fleet, or the German Navy's procedure towards (regional) leading responsibility with its DEU MARFOR and the Baltic Maritime Component Command (BMCC). ${ }^{25}$ Their orientation, particularly its increasing focus on essential components like ASW and surface warfighting, prioritises the relevance of defence capabilities, accurately themed in the Second Fleet's principle "ready to fight". ${ }^{26}$ The extension of interregionally effective air assets throughout the littoral states is another relevant step in substantiating the alliance's posture. ${ }^{27}$ The planned assignment of a Baltic Maritime Coordination Function to bundle NATO's maritime competence in the Baltic will be of further benefit to channelling those capacities into a cross-regional strategy. The necessity of cross-theatre considerations particularly becomes apparent in light of conflict scenarios demanding those means and preparation for the higher end of the escalation ladder.

Considering the aspect of defence and its naval dependence (irrespective of any foregone escalation trigger), the structure of regional and interregional efforts relies primarily on a broad strategic picture. Beyond more traditional threats, the cyber sphere or (covert) operations against high value targets and critical infrastructure must also be factored in. ${ }^{28}$ The operational, trans-regional and therefore strategic link within the Northern waters does also not limit itself to the consequential development of longrange capabilities and prospering "mature precision-strike regimes". ${ }^{29}$ Any large-scale military support originating in North America is urgently con-

25 The "German Maritime Forces", or DEU MARFOR, serve as a naval headquarters for planning and operations, similar to already existing headquarters like, for instance, UK MARFOR or STRIKFORNATO. It represents the core of the Baltic Maritime Component Command, a command centre the German Navy intends to use and provide for allied operations.

26 They compound with already existing elements, such as NATO's Standing Maritime Groups (SNMG and SNMCMG), NATO's Response Force (NRF) and Very High Readiness Joint Task Force (VJTF), or its Force Integration Units (NFIUs).

27 The (naval) airbases in Keflavik, Lossiemouth, Evenes and Nordholz shelter or operate (or intend to perspectively) long-range maritime patrol aircraft (MPA), particularly P-8 Poseidon and P-3C Orion respectively.

28 Like the ports in Antwerp, Rotterdam and Bremerhaven as well as in Tallinn, Riga and Klaipeda.

29 Andrew F. Krepinevich, Maritime Competition in a Mature Precision-Strike Regime (CSBA 2014). https://csbaonline.org/research/publications/maritime-competitionin-a-mature-precision-strike-regime/publication/1; Elfjestad, "Norway and the North Atlantic", 66. 
tingent on secure sea lines of communication (SLOC) ${ }^{30}$ along functioning ports and infrastructure in Europe. ${ }^{31}$ The nature of naval forces mandates, too, that allied naval forces have to prepare for lower-level incidents, most likely in the grey zone. In parallel, they must be ready to adapt their presence towards the higher spectrum of challenges. Beyond that, a potential blockade $^{32}$ of the Baltic Sea at its shallow and narrow access through Danish and Swedish waters is highly dependent on sea control in the North Sea. ${ }^{33}$ Capable naval, air and land assets are necessary to "watch their back", and to be proficient enough to defend power projection and physical intimidation efforts trying to deny allied operations in the region.

Vice versa, if considerable vertical and horizontal escalation arose anywhere, inducing a large-scale military conflict, it could eventually lead to the Russian bastion's "activation" in the High North. ${ }^{34}$ In line with the superordinate aim of guarding the Russian Navy's strategic nuclear submarines (SSBNs), the ultimate pillar of Russia's nuclear triad, such defence aspirations encompass, on the one hand, achieving sea control for the operating area of the inner bastion, namely in the Barents Sea. In addition, denying NATO allies most if not all naval activities in the Norwegian Sea would be of upmost interest to the Russian Navy. Due to the limited number of platforms available, the probability of wide-ranging Russian sea control from Svalbard to the GIUK gap will be limited in the near future. Yet, the capabilities of individual or clustered submarines should not be underrated and remain a central challenge and risk for allied navies. In addition, scenarios include the transfer of air assets to support single Russian combat vessels in the region, hence to expand alarming (long-range) strike regimes, and to eventually boost the thus potentially highly expensive exposure of Western naval assets in light of such operations. ${ }^{35}$ Moreover, Russian proactive measures would not be limited to Northern waters. As pointed out by an expert assessment published by the Norwegian Ministry of Defence, the territorial integrity of NATO member and partner nations

30 This shall include the necessity of secure data flow via the multitude of undersea communication cables on the seabed of the waters.

31 Andrew Metrick, “(Un)Mind the Gap”, USNI Proceedings, vol. 145, No. 10, October 2019. https://www.usni.org/magazines/proceedings/2019/october/unmind-ga p.

32 For example, due to an embargo to apply non-kinetic (political) pressure.

33 See Niklas Granholm's chapter in this volume for a detailed discussion.

34 Harri Mikkola, "The Geostrategic Arctic. Hard Security in the High North", FIIA Briefing Paper 259, April 2019, 5.

35 Zysk, "Russia's Military build-up", 11. 
would be at high risk during such an escalation. ${ }^{36}$ The Scandinavian capitals are aware that their Northern territories would likely be part of alleged Russian multi-domain operations in support of its bastion defence aspirations. ${ }^{37}$

Europe's Northern and Baltic areas meet Russian denial capabilities based on the Kola Peninsula, in Kaliningrad Oblast and in the Western Military District. Those assets are able to hinder the unrestrained operation of naval and air assets in particular. ${ }^{38}$ In line with Sam Tangredi's definition, they intend

"to prevent the attacker from bringing its operationally superior force into the contested region, or, to prevent the attacker from freely operating within the region [while] maximizing its combat power". ${ }^{39}$

Distinguishing this as an acknowledgement of the alliance's full military potential and considering the denial zones' de-mystification ${ }^{40}$ serves to put this picture into perspective. To be clear, the operational risks such installations pose are beyond doubt. Yet, the scrutiny of a broad strategic setting might assist in designing considerations for the alliance to cope with such constraints. Instead of strategists and operators overthinking how to create specific technical solutions, it is crucial that countermeasures are not limi-

36 Such assessment takes place despite the collaboration in other maritime terms, such as fishery or search and rescue efforts. See Expert Commission on Norwegian Security and Defence Policy, "Unified Effort", Oslo: Norwegian Ministry of Defence 2015, 20-21.

37 The bastion concept, parallel to the Russian maritime posture in the region and along its claimed defensive nature, relies notably on offensive means and the willingness to apply them in such a way: to deny any opponent access to particular seas and to defend Russia's own strategic vulnerabilities. See Mikkola, "The Geostrategic Arctic", 5; Allport, "Fire and Ice", 34; Svein Elfjestad "III. The Nordic Region", Whitehall Papers, 93, 1, 46.

38 Robert Dalsjö et al., Bursting the Bubble? Russian A2/AD in the Baltic Sea Region: Capabilities, Countermeasures, and Implications (FOI: Stockholm, March 2019). https:/www.foi.se/rest-api/report/FOI-R--4651--SE.

39 Sam Tangredi, Anti-Access Warfare. Countering A2/AD Strategies (Annapolis: Naval Institute Press, 2013), 2. This is congruent to the observation of today's Russian Navy's tasks, such as serving as the naval defence force to second its Eurasian land power. See Konstantin Bogdanov and Ilya Kramnik, "The Russian Navy in the $21^{\text {st }}$ Century. The Legacy and the New Path", CNA occasional paper, October 2018.

40 Michael Jonsson and Robert Dalsjö, Beyond Bursting Bubbles - Understanding the Full Spectrum of the Russian A2/AD Threat and Identifying Strategies for Counteraction (FOI: Stockholm, June 2020). https://www.foi.se/rest-api/report/FOI-R--4991-SE. 
ted to the particularly threatened domain in order for the alliance to overcome the denial capabilities it is confronted with.

The examinations presented look at the high end of an escalatory hazard. Nevertheless, they are required to prevent deliberate disputes on Europe's Northern Flank. Prevention and deterrence necessitate preparing for diverging scenarios and articulating them in a strategic manner. Signalling readiness and willingness inwards, towards its members, and outwards, aimed at its adversaries, is necessary to underline coherence and illustrate the unviable outcome of any skirmish with the alliance; not only on a military level, but particularly for any challenger's political leadership to desist from belligerent intentions. ${ }^{41}$ Such considerations of the given situation allow the Northern Flank to be seen as NATO en miniature; an area where almost all of the alliance's needs, issues and dynamics are present. The profound aim remains to sustain an adequate deterrence status for the entire region. It contains a decisive military defence posture ${ }^{42}$ and the appropriate transnational political consent to be quick at repartee and not to be deterred oneself to eventually eliminate the idea of a passive alliance that could abandon its members. ${ }^{43}$

41 James H. Bergeron, "Deterrence and Its Maritime Dimension" in Conceptualizing Maritime \& Naval Strategy. Festschrift for Captain Peter M. Swartz, United States Navy (ret.), eds. Sebastian Bruns and Randy Papadopoulos (Baden-Baden: Nomos, 2020), 35-36.

42 Assets and platforms, awareness, readiness and mature operability.

43 ibid.; Likewise, at this stage, it is not sufficient to simply declare red lines for belligerent behaviour. At the high end of military escalation, any player draws such lines, for instance in regard to the deliberate use of conventional military means against its own armed forces, civilians, territory and nuclear deterrence, above all. At the lower end, as Jim Bergeron points out, the difficulty of such efforts is to "deter action both sides solidly believe will not lead to direct conflict." ibid., 42. While deterrence is, by nature, built on the aforementioned red lines, those delimitations, combined with varying deterrence approaches in a single region, include the difficulty of "gap[s] emerging". See Patrick M. Morgan, "Deterrence Now", Cambridge Studies in International Relations 89, Cambridge, UK: Cambridge University Press, 2003, 83. More precisely, with differing defence concepts, the possibility of an aggressor exploiting situations where defence commitments might not be clear is a worrying issue. It is a seam line an opponent would be poised to attack. By using intermediaries, creating faits accomplis, avoiding officially proclaimed red lines or similar measures, adversarial governments such as Russia have succeeded in their goals in the past and still might follow similar procedures in future to achieve their own targets. See ibid., 83 ff.; Van Jackson, "Tactics of Strategic Competition”, Naval War College Review, vol. 70 (2017), No. 3. Art. 4. 


\section{Recommendations for a sustainable allied approach}

The following recommendations relate to several spheres. As Geoffrey Till points out, awareness in relation to surveillance and intelligence is key for any continuative naval measures. ${ }^{44}$ Quoting Alfred Thayer Mahan, who identified intelligence as "one of the very first desiderata of war", Till exerts this observation for times of peace, as well. ${ }^{45}$ As regards literally indepth vigilance, an upgrade in maritime domain awareness "from sea floor to space" 46 in the Baltic, the Norwegian Sea and beyond, embedded within a thorough C4ISR ${ }^{47}$ structure, is inevitable. ${ }^{48}$

Conducting exercises as preliminaries in regard to potential parallel incidents in the Nordic-Baltic and Euro-Atlantic region is needed. They would underscore the central message of this essay, namely to combine efforts in the Baltic Sea and the intersection of the North Atlantic, North Sea and Norwegian Sea. ${ }^{49}$ While the origin of necessity may vary, large-scale cross-theatre drills are advocated, de rigueur involving regional partner nations such as Sweden and Finland. An allied approach should also promote the idea of EU Seapower ${ }^{50}$ and be open to further integration efforts. ${ }^{51}$ In terms of capabilities, planners have to think about how to make use of currently underexposed skills such as “NATO's Amphibious Poten-

44 Geoffrey Till, Seapower. A Guide for the Twenty-First Century, $3^{\text {rd }}$ edition (Routledge: New York 2013), 356.

45 ibid.

46 Department of the Navy, "A Blue Arctic. A Strategic Blueprint for the Arctic", 2021, 14.

47 Command, Control, Communications, Computers, Intelligence, Surveillance and Reconnaissance.

48 Supplementary to the MPA capabilities, efforts can be facilitated with combined undersea networks. Subsequently to the former Sea Surveillance Systems (SOSUS) in the North Atlantic, the deployment of numerous mobile sensors (in conjunction with UUVs, USVs and UAVs) could be beneficial in further areas of interest too, such as notably the Baltic and the Norwegian Seas. See also Metrick, "(Un)Mind the Gap".

49 On the relevance of exercises, see Beatrice Heuser, Termod Heier and Guillaume Lasconjarias, "Military Exercises: Political Messaging and Strategic Impact", NATO Defense College, Forum Paper 26, 2018. https://www.ndc.nato.int/download/ downloads.php? icode $=546$. In this context, see particularly Ryan French's and Peter Dombrowski's chapter on "Exercise BALTOPS".

50 Moritz Brake and Sebastian Bruns, "Building European Seapower: Reinvigorating EU naval strategy and maritime capabilities for the 2020s”, Reprinted from Tidskrift i Sjöväsendet, No.5 (2020), 541-550.

51 A robust European NATO pillar is of most relevance for the alliance to cope with the strategic challenges Russia and China present in the 21st century. It is most 
tial" 52 to strengthen a competent allied deterrence approach. At this point, the combination of blue and green water assets becomes apparent. To identify a sustainable strategic approach and appropriate naval operations on the Northern Flank with the different domains they merge, strategists have to acknowledge that considerations in practice are not limited to "operat[ing] from the sea", but to acting "in the maritime domain." ${ }_{33}$ This does not contradict the alliance's most recent regionalisation efforts. Yet, this domain reflects its expansive nature in terms of the necessity of synergising multiple naval and military aspects for a complete regional approach. Besides its effect onshore, admitting mutual dependency is relevant. Even though designating Northern Europe and the Baltic Sea region in particular as a "wet flank" 54 might be of avail in promoting the maritime sector and its needs in national politics, it undermines the Northern Flank's scope and should be reconsidered. The importance of correct terms and diction becomes clear since allies have repeatedly left misleading narratives for their opponents or got on the wrong track with descriptions and definitions. ${ }^{55}$ This accompanies the wide scale of daily propaganda and disinformation efforts against liberal systems, which are particularly drastic in the Baltic region.

An allied naval approach ought to consider arranging its defensive orientation on enhancing protection measures from a solely "reactive character" 56 towards resolute capabilities, making any aggressor recognise he

likely that their implications, including naval activities, will be apparent on the spot.

52 John D. Williams et al., Unlocking NATO's Amphibious Potential. Lessons from the Past, Insights for the Future (Santa Monica, CA: RAND Corporation, 2020).

53 Vice Admiral Andrew Lewis, Second Fleet Commander, in Lee Willet, "Owning The Battlespace: U.S. Second Fleet Builds North Atlantic Presence”, Jane's Navy International, 10 November 2020.

54 Official German Navy statements include this description frequently. Recent examples are Presse- und Informationszentrum Marine, "Deutsche Marine startet nationale Verbandsübung in der Ostsee”, 31.08.2020, bundeswehr.de. https://ww w.bundeswehr.de/bw-de/organisation/marine/aktuelles/german-exercise-2020-180 2640; “Nasse Flanke Ostsee': Marine startet Übung Northern Coasts”, 03.09.2019, bundeswehr.de. https://www.bundeswehr.de/bw-de/organisation/marine/aktuelle s/marine-startet-uebung-northern-coasts-103264.

55 From the rediscovering of "A2/AD" in regard to Russian capabilities, the assumed "Gerasimov doctrine" and an upcoming "hyper hype", to disorientation due to another "Battle for the Atlantic", samples are manifold. The latter has been analysed recently by Steve Wills. See Wills, "SLOCs".

56 Elfjestad, "Norway and the North Atlantic", 67. 
would fall behind after initiating any form of malicious escalation. ${ }^{57}$ While not decreasing the preceding deterrence-by-denial posture, adding additional weight to deterrence-by-punishment is advisable. However, invigorating the existing allied deterrence posture in such a way depends heavily on strategic signalling that essentially incorporates the above-mentioned readiness and willingness of the alliance's political and military leadership. ${ }^{58}$

Strategic maritime considerations are not confined to (high-end) naval warfighting advisements, although such considerations might be correctly assumed to be a priority for a military alliance. Yet, as NATO's Alliance Maritime Strategy emphasises, supplementary to deterrence and defence, maritime forces have to comply with a wide spectrum of contributions to fulfil the aim of eventually maintaining pan-regional security. ${ }^{59}$ Complementary to this subject, enabling wide-ranging maritime domain awareness, as already pointed out, or intensifying SAR capabilities and cooperation has the potential of strengthening regional structures. Sustaining SLOCs and access to the Arctic with its potential of new passage due to receding polar ice is of additional relevance, whilst environmental protection and human security offer plenty of opportunities for engagement out-

57 This should include concerted elements to challenge the aforementioned denial capabilities in the region.

58 In this context, a US Navy concept from the 1980s becomes relevant. As Bradford Dismukes points out, in addition to anti-submarine warfare (ASW) in the North Atlantic and the Norwegian Sea, strategic ASW is contextualised in the US's (but not necessarily NATO) deterrence and sea denial posture on the Northern Flank. See Dismukes, "Great-Power-Competition", 14-15; Nordenman, "North Atlantic", 200-201. Neither confirmed nor denied officially, the approach of targeting Russian SSBNs and therefore the essential pillar of their nuclear triad appears to be a double step on both the vertical and horizontal escalation ladder. While, two steps before, pursuing long-range capabilities and the ability to target Russian key locations, for example on the Kola peninsula, is a legitimate conventional deterrent, the targeting of SSBNs and hazarding the consequences of high escalatory risks is a tense tightrope walk. The goal of "threatening-or even seeming to threaten-those interests of great value to Russian leaders [...] could just as easily provoke escalation as induce restraint" and would therefore, with its risks and consequences for the entire alliance, supersede any present benefit. See Michael Fitzsimmons, "Horizontal Escalation: An Asymmetric Approach to Russian Aggression?", Strategic Studies Quarterly, vol. 13 No. 1 (Spring 2019), 120, 123. Dismukes, "Great-Power-Competition", 14-15.

59 Notably, also Cooperative and Maritime Security measures. See NATO, "Alliance Maritime Strategy”, 2011, I. 2. https:/www.nato.int/cps/en/natohq/official_texts_ 75615.htm. 
side allied membership as well. However, they remain beyond the scope of this chapter.

Nevertheless, comprehension of the bigger picture is an important goal too. Bringing together practitioners, scholars and decision makers from complementary disciplines to discuss this approach could prepare the intellectual ground for its implementation. ${ }^{60}$ This does not aim at creating another regional security arrangement, since there are plenty in existence. ${ }^{61}$ A possibility would be to merge and consolidate their output under an allied umbrella, such as a dedicated Northern Strategic Forum. ${ }^{62}$ Centring the common strategic orientation, such conventions could advance each participant nation's approach and its ability to strategise in an allied manner. To address and challenge national projections might eventually help in formulating a collective maritime attitude, which has to evolve into strategic concepts and operations, and nothing less.

\section{Conclusion}

This chapter has called for a broad and common allied naval approach towards Europe's Northern Flank. Whereas the first part delved into defining the region's basics and explained the relevance of addressing them with broad lenses, the second part, recalling recommended actions, touches on elements of deterrence, intellectual development and the implementation of operative needs. While selected recommendations for action are more distinct, some elements, due to the nature of formulating strategic propositions, maintain rather vague intentions. What becomes clear is that any strategic concept for the $21^{\text {st }}$ century Northern Flank calls for frequent revision by strategic planners. ${ }^{63}$ It remains relevant to bear in mind that any of the alliance's aims ultimately represents the collective agreements of its member states. Consequently, keeping up integrity and coherence is essential for its productive existence. Although governments change and partic-

60 See also: Jonathan D. Caverley and Peter Dombrowski, "Too important to Be Left to the Admirals. The Need to Study Maritime Great-Power Competition”, Security Studies, vol. 29, issue 4 (2020), 579-600.

61 For a well-arranged depiction of the multitude of Northern-Baltic security arrangements and institutions, see Lange et al., "To The Seas Again", 3.

62 The Kiel International Seapower Symposia provide examples of high-level maritime strategy gatherings on neutral ground, which is either civilian or non-partisan.

63 Bergeron, 49-50. 
ular attitudes vary, deep-seated alliances and their strategies can figure as guide rails for their member states' policies and, in case of doubt, recall their covenant values. ${ }^{64}$ Hence, it is crucial to acknowledge a common Northern Flank approach as a merged and unified strategy of heterogeneous valuations. Bridging the gaps, symbolically speaking, is an adjuvant way of accomplishing such an approach.

\section{Works Cited}

Allport, Rowan. Fire and Ice - A New Maritime Strategy for NATO's Northern Flank. Human Security Centre 2018, http://www.hscentre.org/wp-content/uploads/201 8/11/Fire-and-Ice-A-New-Maritime-Strategy-for-NATOs-Northern-Flank.pdf.

Bergeron, James H. "Deterrence and Its Maritime Dimension." In Conceptualizing Maritime \& Naval Strategy. Festschrift for Captain Peter M. Swartz, United States Navy (ret.), edited by Sebastian Bruns and Randy Papadopoulos, 33-50. BadenBaden: Nomos, 2020.

Black, James, Flanagan, Stephen J., Germanovich, Gene, Harris, Ruth, Ochmanek, David, Favaro, Marina, Galai, Katerina and Ryen Gloinson, Emily. Enhancing deterrence and defence on NATO's northern flank. Allied perspectives on strategic options for Norway. Santa Monica, CA: RAND Corporation, 2020, https://www.ran d.org/pubs/research_reports/RR4381.html.

Bogdanov, Konstantin and Kramnik, Ilya, "The Russian Navy in the $21^{\text {st }}$ Century. The Legacy and the New Path", CNA occasional paper, October 2018, https://w ww.cna.org/CNA_files/PDF/IOP-2018-U-018268-Final.pdf.

Bosack, Michael M. "Ameliorating the Alliance Dilemma in an Age of Grey-Zone Conflict-Lessons Learned from the U.S. -Japan Alliance", Naval War College Review, vol. 73 (2020), No. 4, Article 5.

Brake, Moritz and Bruns, Sebastian, "Building European Seapower: Reinvigorating EU naval strategy and maritime capabilities for the 2020s", Reprinted from Tidskrift i Sjöväsendet, No. 5 (2020), 541-550.

Caverley, Jonathan D. and Dombrowski, Peter, "Too important to Be Left to the Admirals. The Need to Study Maritime Great-Power Competition", Security Studies, vol. 29, Issue 4 (2020), 579-600.

Dalsjö, Robert, Berglund, Christofer and Jonsson, Michael. Bursting the Bubble? Russian A2/AD in the Baltic Sea Region: Capabilities, Countermeasures, and Implications. FOI: Stockholm, March 2019, https://www.foi.se/rest-api/report/FOI-R--46 51-SE.

64 ibid. 
Department of the Navy, "A Blue Arctic. A Strategic Blueprint for the Arctic", 2021, https://media.defense.gov/2021/Jan/05/2002560338/-1/-1/0/ARCTIC\%20BL UEPRINT\%202021\%20FINAL.PDF/ARCTIC\%20BLUEPRINT\%202021\%20FI NAL.PDF.

Dismukes, Bradford, "The Return of Great-Power Competition-Cold War Lessons about Strategic Antisubmarine Warfare and Defense of Sea Lines of Communication", Naval War College Review, vol. 73 (2020) No. 3, Art. 6.

Dyndal, Gjert Lage, "The Northern Flank and the High North Scenarios of the Cold War", Paper held at conference: 'Peripherie oder Kontaktzone? Die NATOFlanken 1961 bis 2013', Zentrum für Militärgeschichte und Sozialwissenschaften der Bundeswehr, Potsdam, Germany, 2013, https://core.ac.uk/downl oad/pdf/52118533.pdf.

Elfjestad, Svein, "III. The Nordic Region”, Whitehall Papers, 93, 1 (2018), 37-48.

Elfjestad, Svein, "Norway and the North Atlantic: Defence of the Northern Flank", Whitehall Papers, 87, 1 (2017), 59-75.

Expert Commission on Norwegian Security and Defence Policy. Unified Effort. Oslo: Norwegian Ministry of Defence, 2015, https:/www.regjeringen.no/globala ssets/departementene/fd/dokumenter/unified-effort.pdf.

Fitzsimmons, Michael, "Horizontal Escalation: An Asymmetric Approach to Russian Aggression?”, Strategic Studies Quarterly, vol. 13, No 1, Spring 2019, 95-133.

Jackson, Van, “Tactics of Strategic Competition”, Naval War College Review, vol. 70 (2017), No. 3. Art. 4.

Jonsson, Michael and Dalsjö, Robert, Beyond Bursting Bubbles - Understanding the Full Spectrum of the Russian A2/AD Threat and Identifying Strategies for Counteraction. FOI: Stockholm, June 2020, https://www.foi.se/rest-api/report/FOI-R--4991-SE.

Krepinevich, Andrew F., Maritime Competition in a Mature Precision-Strike Regime. CSBA 2014, https://csbaonline.org/research/publications/maritime-competitionin-a-mature-precision-strike-regime/publication/1.

Kühn, Ulrich, "Preventing Escalation in the Baltic. A NATO Playbook", Carnegie Endowment for International Peace, 2018, https://carnegieendowment.org/files/ Kuhn_Baltics_INT_final_WEB.pdf.

Lange, Heinrich, Combes, Bill, Jermalavičius, Tomas and Lawrence, Tony, To the Seas Again. Maritime Defence and Deterrence in the Baltic Region. Tallinn: ICDS, April 2019, https://icds.ee/wp-content/uploads/2019/04/ICDS_Report_To_the_S eas_Again_Lange_Combes_Jermalavicius_Lawrence_April_2019.pdf.

Metrick, Andrew, “(Un)Mind the Gap”, USNI Proceedings, vol. 145, No. 10, October 2019, https://www.usni.org/magazines/proceedings/2019/october/unmind-gap.

Meyer zum Felde, Rainer, "Abschreckung und Dialogbereitschaft - der Paradigmenwechsel der NATO seit 2014“, SIRIUS - Zeitschrift für Strategische Analysen, vol. 2 (2), 2018, 101-117.

Mikkola, Harri, "The Geostrategic Arctic. Hard Security in the High North", FIIA Briefing Paper 259, April 2019, https:/www.fiia.fi/wp-content/uploads/2019/04/ bp259_geostrategic_arctic.pdf. 
Morgan, Patrick M., "Deterrence Now", Cambridge Studies in International Relations 89, Cambridge, UK: Cambridge University Press, 2003.

Murphy, Martin, Hoffmann, Frank G. and Schaub, Gary Jr., Hybrid Maritime Warfare and the Baltic Sea Region. Copenhagen: Centre for Military Studies, November 2016, https://cms.polsci.ku.dk/publikationer/Hybrid_Maritime_Warfare_an d_the_Baltic_Sea_Region.pdf.

Nordenman, Magnus, The New Battle for the Atlantic. Emerging Naval Competition with Russia in the Far North. Annapolis: Naval Institute Press, 2019.

Pawlak, Julian and Bruns, Sebastian, "Die Ostsee ist nicht Las Vegas. Das Mare Balticum im sicherheitspolitischen Kontext”, MarineForum, 6-2019, 20-35.

Pincus, Rebecca, "Towards a New Arctic. Changing Strategic Geography in the GIUK Gap”, the RUSI Journal, vol 165, Issue 3 (2020), 50-58.

Rhode, Benjamin, “The GIUK gap's strategic significance”, IISS Strategic Comments, vol. 25, Comment 29, October 2019, https:/www.iiss.org/ /publication/799791d d-7be1-4484-abfd-05fa3a400889/the-giuk-gaps-strategic-significance.pdf.

Shlapak, David A. and Johnson, Michael, "Reinforcing Deterrence on NATO's Eastern Flank. Wargaming the Defense of the Baltics", Santa Monica, CA: RAND Corporation, 2016, https://www.rand.org/pubs/research_reports/RR1253 .html-.

Stöhs, Jeremy, "Bastion, Backwater, or Battlefront? Changing Strategic Views Along Europe's Northern Shores.” In Conceptualizing Maritime \& Naval Strategy. Festschrift for Captain Peter M. Swartz, United States Navy (ret.), edited by Sebastian Bruns and Randy Papadopoulos, 321-344. Baden-Baden: Nomos, 2020.

Tangredi, Sam, Anti-Access Warfare. Countering A2/AD Strategies. Annapolis: Naval Institute Press, 2013.

Till, Geoffrey, Seapower. A Guide for the Twenty-First Century. $3^{\text {rd }}$ edition. Routledge: New York, 2013.

United States Department of Defense, "Report to Congress. Department of Defense Arctic Strategy", Office of the Under Secretary of Defense for Policy, June 2019, https://media.defense.gov/2019/Jun/06/2002141657/-1/-1/1/2019-DOD-AR CTIC-STRATEGY.PDF.

Willet, Lee, "Owning The Battlespace: U.S. Second Fleet Builds North Atlantic Presence”, Jane's Navy International, 10 November 2020.

Williams, John D., Germanovich, Gene, Webber, Stephen and Tarini, Gabrielle, Unlocking NATO's Amphibious Potential. Lessons from the Past, Insights for the Future. Santa Monica, CA: RAND Corporation, 2020, https://www.rand.org/pubs/ perspectives/PEA695-1.html.

Wills, Steve, “These aren't the SLOC's you're looking for': mirror-imaging battles of the Atlantic won't solve current Atlantic security needs", Defense \& Security Analysis, 36, 1 (2020), 30-41.

Zysk, Katarzyna, "Russia's Military Build-Up in the Arctic: to What End?" CNA occasional paper, September 2020, https://www.cna.org/CNA_files/PDF/IOP-2020U-027998-Final.pdf. 
